\title{
Responses of Creeping Bentgrass to Trinexapac-ethyl and Biostimulants under Summer Stress
}

\author{
Yan Xu and Bingru Huang ${ }^{1}$ \\ Department of Plant Biology and Pathology, Rutgers University, Room 301 \\ Foran Hall, 59 Dudley Road, New Brunswick, NJ 08901
}

Additional index words. creeping bentgrass, Agrostis stolonifera, summer stress, plant growth regulator, trinexapac-ethyl, CPR, TurfVigor

\begin{abstract}
Summer decline in turf quality and growth of cool-season grass species is a major concern in turfgrass management. The objectives of this study were to investigate whether foliar application of trinexapac-ethyl (TE) and two biostimulants (TurfVigor and CPR) containing seaweed extracts would alleviate the decline in creeping bentgrass (Agrostis stolonifera $\mathbf{L}$.) growth during summer months and to examine effects of TE and the biostimulants on leaf senescence and root growth. The study was performed on a 'Penncross' putting green built on a sandy loam soil at Hort Farm II, North Brunswick, NJ, in 2007 and 2008. Turf was foliar-sprayed with water (control), TE (0.05 kg a.i./ha), TurfVigor $\left(47.75 \mathrm{~L} \cdot \mathrm{ha}^{-1}\right)$, or CPR $\left(19.10 \mathrm{~L} \cdot \mathrm{ha}^{-1}\right)$ from late June to early September in a 2 -week interval in both years. Turf quality, density, chlorophyll content, canopy photosynthetic rate $\left(P_{n}\right)$, and root growth exhibited significant decline during July and August in both 2007 and 2008, to a greater extent in each parameter for the control treatment. Foliar application of TE resulted in significant improvement in turf quality, density, chlorophyll content, and $P_{n}$ on certain sampling dates from July to September in both years compared with the control. Both TurfVigor and CPR significantly improved visual quality during July and August in both years by promoting both shoot and root growth. This study suggests that proper application of TE and selected biostimulants could be effective to improve summer performance of creeping bentgrass.
\end{abstract}

Creeping bentgrass (Agrostis stolonifera L.) is a widely used cool-season grass species for golf course putting greens. It grows vigorously during spring and fall when growth temperatures are 18 to $24{ }^{\circ} \mathrm{C}$ for shoots and 10 to $18{ }^{\circ} \mathrm{C}$ for roots (Beard, 1973). Turf quality declines on creeping bentgrass greens during summer months when temperature exceeds the optimum, which is characterized by thinning turf canopy, leaf senescence, and root dieback (Carrow, 1996). Heat stress is found to be the primary factor leading to summer bentgrass decline (Huang, 2001). Many physiological factors have been associated with heat stress injury in cool-season grass species, including inhibition of photosynthesis, reduction in water and nutrient uptake, and hormone synthesis (Fry and Huang, 2004; Huang and $\mathrm{Xu}, 2000$; Liu and Huang, 2005). Root growth has been found to be more sensitive to heat stress than shoots and root dieback precedes decline in turf quality for creeping

Received for publication 16 Sept. 2009. Accepted for publication 16 Nov. 2009.

We thank United States Golf Association, Ocean Organics, and Novazymes for funding support. Thanks also go to T.J. Lawson and Joseph Clarke for technical assistance in the field and to Dr. Chenping $\mathrm{Xu}$ and Emily Merewitz for critical review of the manuscript.

${ }^{1}$ To whom reprint requests should be addressed; e-mail huang@aesop.rutgers.edu. bentgrass (Beard and Daniel, 1966; Xu and Huang, 2000). Root dieback inhibits the production of cytokinins, a class of plant hormones that are primarily produced in roots, which in turn affect shoot growth and senescence (Adeldipe et al., 1971; Henson and Wareing, 1976; Udomprasert et al., 1995). Incorporation of management practices such as use of natural products or plant growth regulators that may promote shoot and root growth would favor creeping bentgrass survival in the summer.

A plant growth regulator (PGR), trinexapacethyl (TE; Syngenta Crop Protection, Greensboro, NC), has been widely used in turfgrass management for clipping reduction, seedhead suppression of annual bluegrass (Poa annua L.), and improvement of overall turf quality in various turfgrass species (Borger, 2008; Fagerness et al., 2002; Lickfeldt et al., 2001; McCullough et al., 2005). It belongs to gibberellic acid (GA) inhibitors and blocks the conversion of $\mathrm{GA}_{20}$ to $\mathrm{GA}_{1}$, the final step in GA biosynthesis pathway (Adams et al., 1992; King et al., 1997) leading to the inhibition of cell expansion in sheaths and basal regions of leaves (Kaufmann, 1986). Recently, TE has been found to be effective in improving turf performance under such adverse conditions as shade (Ervin et al., 2004; Goss et al., 2002), freezing (Fagerness et al., 2002), heat tolerance (Wang et al., 2006), and combined drought and heat stress (McCann and Huang, 2007). Despite the wide use of
TE in bentgrass green management, the physiological effects of TE application associated with summer bentgrass decline are not well documented. TE has been reported to cause increases in chlorophyll content and shoot density in various turfgrass species (Ervin and Koski, 1998, 2001; Fagerness and Yelverton, 2001; Stier and Rogers, 2001). As discussed earlier, the typical symptoms of summer bentgrass decline are leaf senescence and a reduction in overall canopy leaf density. Therefore, it is hypothesized that foliar application of TE may alleviate summer bentgrass decline by suppressing leaf senescence and promoting a denser turf canopy during summer months.

In addition to PGRs, some biostimulant products were developed to improve turfgrass quality, especially in turf that is under environmental or cultural stress (Karnok, 2000). Among a variety of a.i. in biostimulants, one ingredient common to many biostimulant products is seaweed extract, which is rich in organic and mineral compounds and often exhibit activity of plant hormones such as cytokinins and auxin (Sanderson et al., 1987; Tay et al., 1985; Wells et al., 2003). Some biostimulant products may increase soil microbial density and activity by incorporating microbial inoculums, which in turn enhances turfgrass quality through increased organic matter decomposition and improved nutrient availability (Mueller and Kussow, 2005). Exogenous application of seaweed extracts has been observed to improve growth, yield, and stress tolerance of many crops such as wheat (Triticum aestivum L.) (Bokil et al., 1974), tomato (Lycopersicon esculentum L.) (Crouch and van Standen, 1992), and soybean [Glycine $\max (\mathrm{L}$.$) Merr]$ (Rathore et al., 2009). Zhang et al. (2003) found seaweed extract could be a beneficial supplement for reducing standard fertilizer and fungicide inputs while maintaining adequate creeping bentgrass health. However, knowledge of effects of seaweed-based biostimulants on turfgrass growth under heat stress conditions is still limited and the mechanisms for the effects remain largely unknown. With the increasing use of biostimulants on creeping bentgrass putting greens, the information on whether and how the biostimulants affect creeping bentgrass summer performance would help turf managers develop more efficient summer stress management practices.

The objectives of this study were to investigate whether foliar application of $\mathrm{TE}$ and two biostimulants containing seaweed extracts would alleviate decline in creeping bentgrass growth during summer months and to examine the effects of $\mathrm{TE}$ and the biostimulants on leaf senescence and root growth. Shoot growth and leaf senescence of creeping bentgrass were examined by measuring turf quality, turf density, leaf chlorophyll content, and canopy net photosynthetic rate. Root growth was examined by measuring total root surface area and root biomass. 


\section{Materials and Methods}

Plant materials and growing conditions. The experiment was performed on a 'Penncross' creeping bentgrass green built on a root-zone mixture consisting of mediumsized sand meeting USGA size guidelines (Green Section Staff, 1993) and sphagnum peat (9:1 in volume) at Hort Farm II, North Brunswick, NJ. An on-site weather station was located $\approx 130 \mathrm{~m}$ from the experimental site to record daily meteorological parameters. The green was mowed $6 \mathrm{~d}$ per week at 4 $\mathrm{mm}$ and clippings were removed. It was irrigated daily to replace $100 \%$ evapotranspiration water loss. A $16-4-8\left(\mathrm{~N}-\mathrm{P}_{2} \mathrm{O}_{5}-\mathrm{K}_{2} \mathrm{O}\right)$ fertilizer was applied in April, June, and September at a rate of $122 \mathrm{~kg} \cdot \mathrm{ha}^{-1}$ of nitrogen in 2007 and 2008 to maintain adequate soil nutrient status. Fungicides [Spectro 90WDG (Cleary Chemical Corporation, Dayton, NJ), Daconil Ultrex (Syngenta Crop Protection, Inc., Greensboro, NC), Pentathlon (Agrisel USA, Inc., Suwanee, GA), and Banner Maxx (Syngenta Crop Protection, Inc.)] were applied on a curative basis mainly to control dollar spots and brown patch.

Treatments and experimental design. The two biostimulants used were CPR (Emerald Isle Solutions, Ann Arbor, MI) and TurfVigor (Novozymes Biologicals Inc., Salem, VA). CPR is a blend of natural sea plant extract, micronutrients, and a surfactant agent. It contains $4 \%$ nitrogen $(\mathrm{N}), 1 \% \mathrm{~K}_{2} \mathrm{O}, 0.53 \%$ magnesium, $1 \%$ sulfur, $2 \%$ iron $(\mathrm{Fe}), 0.25 \%$ manganese (Mn), and $0.2 \%$ zinc ( $\mathrm{Zn})$. TurfVigor is a formulation containing $0.014 \%$ patented microbial strains (Bacillus sp. and Paenbacillus sp.) along with kelp extract and macroand micronutrients. This product contains $9 \%$ $\mathrm{N}, 3 \% \mathrm{P}_{2} \mathrm{O}_{5}, 6 \% \mathrm{~K}_{2} \mathrm{O}, 0.6 \% \mathrm{Fe}, 0.05 \% \mathrm{Mn}$, and $0.05 \% \mathrm{Zn}$. All three products were applied following their respective manufacturer's recommended rates: 1) TE (120 g a.i./L emulsifiable concentrate): $0.05 \mathrm{~kg}$ a.i./ha; 2) TurfVigor: $47.75 \mathrm{~L} \cdot \mathrm{ha}^{-1}$; and 3) CPR: 19.10 $\mathrm{L} \cdot \mathrm{ha}^{-1}$. The water volume applied for control and carry volume for TurfVigor, CPR, and TE was 2 gallon per $1000 \mathrm{ft}^{2}$. Water (control) treatment was also included in the experiment. Each control plot was treated with the same volume of water as the volume of TE or biostimulant solutions sprayed on treated plots. Treatments were applied using a $\mathrm{CO}_{2}$ pressurized backpack sprayer on 23 June, 6 July, 25 July, 8 Aug., 24 Aug., and 7 Sept. in 2007 and on 11 June, 27 June, 11 July, 28 July, 13 Aug., and 27 Aug. in 2008.

The experiment was a completely randomized design with four replicates or plots $(0.76 \times 1.22 \mathrm{~m}$ each plot $)$ for each treatment.

Measurements. All measurements were taken 2 weeks after each spray was applied. Overall turf performance was evaluated by rating turf quality (TQ) based on color, density, and uniformity of the grass canopy using a 0 to 9 scale ( 9 representing fully green, dense turf canopy and 0 representing completely dead plants) (Beard, 1973). A rating of 6 was considered to be the minimum acceptable TQ for a putting green.
Leaf chlorophyll was extracted from $\approx 0.1 \mathrm{~g}$ of fresh leaves incubated in $10 \mathrm{~mL}$ dimethyl sulfoxide in the dark for $72 \mathrm{~h}$. The absorbance of the leaf extracts was determined using a spectrophotometer (Spectronic Genesys2; Spectronic Instruments, Rochester, NY). Chlorophyll content (CHL) was calculated based on the absorbance at $663 \mathrm{~nm}$ and $645 \mathrm{~nm}$ using the formulas described by Arnon (1949).

Canopy reflectance characteristics of turf plots were measured with a handheld multispectral radiometer (MSR) (Cropscan, Rochester, MN) on clear and sunny days between 1100 and 1400 HR. The MSR scanned a fixed surface area of each plot (a circular area of $\approx 0.7 \mathrm{~m}^{2}$ ), providing an additional measurement to visual estimates of turf quality by spectral assessment of canopy characteristics. The ratio of near intrared $(935 \mathrm{~nm})$ to red $(661 \mathrm{~nm})$ is correlated to turf visual quality, shoot density, and stress injury level in warm-season and cool-season turfgrass species (Trenholm et al., 1999; Jiang and Carrow, 2005, 2007) and used to estimate leaf area index or shoot density in crops (Asrar et al., 1984; Hatfield et al., 1983) and turfgrasses (Trenholm et al., 1999).

Canopy photosynthetic rate $\left(\mathrm{P}_{\mathrm{n}}\right)$ was measured using a gas exchange analyzer with a canopy chamber constantly providing 400 $\mu \mathrm{L} \cdot \mathrm{L}^{-1} \mathrm{CO}_{2}$ (LI-COR 6400; LI-COR Biosciences, Lincoln, NE). The canopy chamber consisted of an acrylic cylinder $(10 \mathrm{~cm}$ diameter and $8 \mathrm{~cm}$ height), which was pressed into the ground $\approx 3 \mathrm{~cm}$ to provide an adequate seal for canopy gas exchange measurements (DaCosta and Huang, 2006). Photosynthesis measurements were performed on clear and sunny days between 1100 and $1400 \mathrm{HR}$ at times of maximal solar radiation.

Root samples were collected from three soil cores (15 cm deep, $76-\mathrm{cm}^{3}$ soil core) randomly located within each plot. Roots were washed free of soil and scanned on a flatbed color scanner. Total root surface area (including root length and diameter) per square meter of turf canopy $\left(\mathrm{m}^{2} \cdot \mathrm{m}^{-2}\right.$ turf canopy) was quantified using WinRhizo software (Regent Instruments, Quebec, Canada). Roots were then oven-dried at $80{ }^{\circ} \mathrm{C}$ for $7 \mathrm{~d}$ and measured for dry weight (DW). Root biomass was expressed as root DW per square meter of turf canopy $\left(\mathrm{g} \mathrm{DW} / \mathrm{m}^{2}\right.$ turf canopy).

Statistical analysis. Analysis of variance was based on the general linear model procedure of SAS 9.1 (SAS Institute Inc., Cary, NC). Effects of chemical treatments were tested using analysis of variance. Treatments were compared separately for each sampling date in each year. Treatment differences were separated by Fisher's protected least significant difference (LSD) test at the $0.05 P$ level. LSD bars were present in the figures when significant chemical effects were detected.

\section{Results}

Yearly interactions were significant for all the parameters so that the 2007 and 2008 data for each parameter were presented separately.
Turf quality. In 2007, TQ in all plots gradually declined from 3 July to 4 Sept. and showed partial recovery on 17 Sept. (Fig. 1A). Plots sprayed with CPR and TurfVigor consistently maintained $22 \%$ to $100 \%$ higher TQ than the control plots on all sampling dates. TQ of TE-treated plots was not different from that of the control plots between 3 July and 1 Aug. However, on 14 Aug., 4 Sept., and 19 Sept., TE treatment improved TQ by $37 \%, 62 \%$, and $29 \%$, respectively, compared with the control plots.

In 2008, TQ declined from 24 June to 9 Aug. and recovered to some extent after 26 Aug. in all plots (Fig. 1B). CPR and TurfVigor treatments consistently increased TQ by $6 \%$ to $28 \%$ on all sampling dates compared with the control plots. Plots treated with TE maintained $8 \%$ to $18 \%$ higher TQ than the control plots on all sampling dates except 24 June.

Turf density. Turf density was estimated as the ratio of $R_{935} / R_{661}$. The ratio of $R_{935} /$ $\mathrm{R}_{661}$ for all plots declined from 3 July to 4 Sept. and then increased to above the July level on 17 Sept. in 2007 (Fig. 2A). The $\mathrm{R}_{935} /$ $\mathrm{R}_{661}$ ratio of CPR-treated plots was $11 \%$, $14 \%$, and $16 \%$ higher than that in the control plots on 17 July, 1 Aug., and 14 Aug., respectively. Plots sprayed with TE also maintained $9 \%$ and $14 \%$ higher $R_{935} / R_{661}$ ratio on 1 Aug. and 14 Aug. compared with the control plots. The ratio of $\mathrm{R}_{935} / \mathrm{R}_{661}$ in TurfVigor-treated plots were $16 \%$ to $27 \%$ higher from 17 July to 14 Aug. and also recovered more quickly and maintained $27 \%$ higher on 19 Sept. compared with the control plots.

The $R_{935} / R_{661}$ ratio in 2008 followed a similar pattern of changes as that in 2007 with a graduate decline from 24 June to 26 Aug. for all plots and then recovered to above the June level on 10 Sept. (Fig. 2B). The ratio was $12 \%$ to $18 \%$ higher in plots sprayed with TurfVigor than the ratio of the control plots. TE-treated plots also maintained $12 \%$ and $14 \%$ higher $\mathrm{R}_{935} / \mathrm{R}_{661}$ on 26 Aug. and 10 Sept. than the control plots. There was no significant difference in $\mathrm{R}_{935} / \mathrm{R}_{661}$ between CPR-treated plots and the control plots in 2008.

Chlorophyll content. In 2007, CHL in all plots declined from 3 July to 4 Sept. and increased to the same or above the July level on 17 Sept. (Fig. 3A). TurfVigor-treated plots consistently maintained $22 \%$ to $76 \%$ higher CHL than the control plots. CPR treatment resulted in $53 \%$ and $61 \%$ higher CHL content on 14 Aug. and 19 Sept., respectively, compared with the control plots. Plots sprayed with TE maintained 53\% higher CHL than the control plots on 14 Aug.

In 2008, CHL of control plots exhibited significant decline from 24 June to 9 Aug., whereas CHL in all other treatments declined until 25 July and then recovered to above the June level on 10 Sept. (Fig. 3B). CPR-treated plots maintained $79 \%, 22 \%$, and $22 \%$ higher CHL than the control plots on 9 Aug., 26 Aug., and 10 Sept., respectively. Plots sprayed with TurfVigor had 67\% and 29\% 


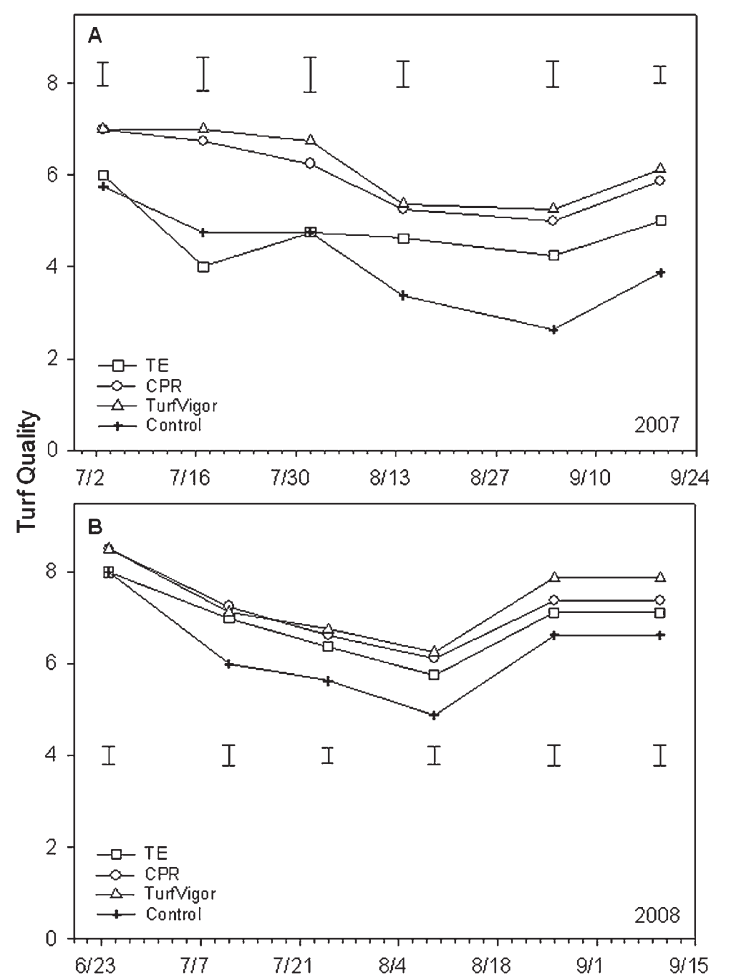

Fig. 1. Effects of TE, CPR, TurfVigor, and control treatments on turf quality of creeping bentgrass during the experimental period in 2007 (A) and 2008 (B). Vertical bars indicate least significant differences (1sds) $(P \leq 0.05)$ for treatment comparison at a given day of treatment. 1sds $(P \leq 0.05)$ for comparison among the samplings dates in 2007 are $0.71,0.53,0.44$, and 0.73 in TE, CPR, TurfVigor, and control treatments, respectively; 1sds $(P \leq 0.05)$ for comparison among the samplings dates in 2008 are 0.44 , $0.44,0.28$, and 0.29 in TE, CPR, TurfVigor, and control treatments, respectively. The lsd bars were not presented on sampling dates when treatment effects were not significant.

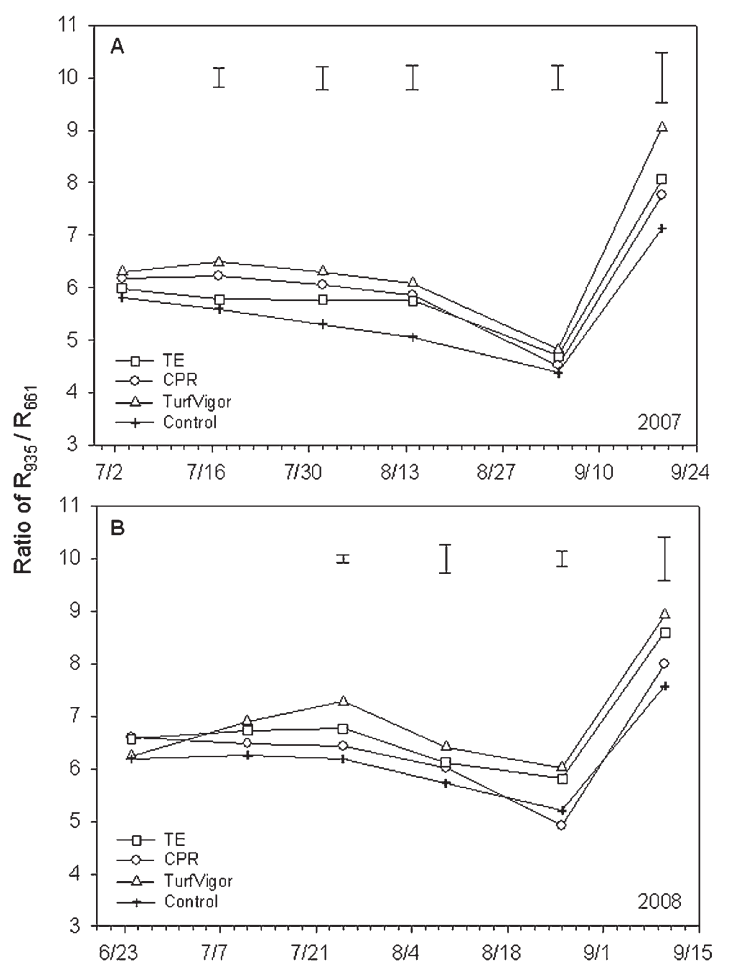

Fig. 2. Effects of TE, CPR, TurfVigor, and control treatments on turf density estimated as $R_{935} / R_{661}$ of creeping bentgrass during the experimental period in 2007 (A) and 2008 (B). Vertical bars indicate least significant differences (lsds) $(P \leq 0.05)$ for treatment comparison at a given day of treatment. 1sds $(P \leq$ 0.05 ) for comparison among the samplings dates in 2007 are $0.59,0.76,0.82$, and 0.37 in TE, CPR, TurfVigor, and control treatments, respectively; lsds $(P \leq 0.05)$ for comparison among the samplings dates in 2008 are $0.64,0.68,0.75$, and 0.34 in TE, CPR, TurfVigor, and control treatments, respectively. The lsd bars were not presented on sampling dates when treatment effects were not significant. higher CHL than the control plots on 9 Aug. and 26 Aug., respectively. TE treatment increased CHL by $47 \%$ on 9 Aug. compared with the control plots.

Canopy net photosynthetic rate. In 2007, canopy $\mathrm{P}_{\mathrm{n}}$ gradually declined from 3 July to 14 Aug. for all plots followed by a full recovery in CPR and TurfVigor-treated plots and a partial recovery in TE-treated plots and control plots on 4 Sept. (Fig. 4A). TurfVigortreated plots maintained $12 \%$ to $64 \%$ higher $\mathrm{P}_{\mathrm{n}}$ than the control plots on all sampling dates. TE-treated plots exhibited $18 \%$ higher $\mathrm{P}_{\mathrm{n}}$ only on 4 Sept. compared with the control plots. CPR treatment had no significant effects on canopy $P_{n}$ on any sampling date

In 2008, canopy $\mathrm{P}_{\mathrm{n}}$ declined from 24 June to 9 Aug. and then recovered to above the June level for all plots (Fig. 4B). The greatest $\mathrm{P}_{\mathrm{n}}$ reduction was observed on 9 Aug. in the control plots ( $35 \%$ of the initial level in June), and the smallest reduction was in TurfVigortreated plots ( $18 \%$ of the initial). Statistically significant treatment effects on $\mathrm{P}_{\mathrm{n}}$ was only detected in TE-treated plots on 24 June and in TurfVigor-treated plots on 25 July compared with the control plots. There was no significant difference in $\mathrm{P}_{\mathrm{n}}$ between CPR-treated and the control plots.

Root growth. TurfVigor treatment resulted in significantly larger root surface area than control treatment on 14 Aug. in 2007 and 10 Sept. in 2008 (Fig. 5A-B). CPR and TE treatments did not affect root surface area. Root biomass gradually decreased for all plots during the whole experimental period in both years. It declined by $54 \%$ on 19 Sept. in 2007 and $67 \%$ on 10 Sept. in 2008 , respectively, in the control plots. In 2007, plots sprayed with TurfVigor and TE maintained greater root biomass than the control plots on 17 July and 14 Aug. (Fig. 6A). In 2008, greater root biomass was observed in CPR-treated plots on 10 Sept. and in TurfVigor-treated plots on 26 Aug. and 10 Sept. compared with the control plots (Fig. 6B).

\section{Discussion}

Overall turf performance of creeping bentgrass evaluated by TQ declined in both summers in 2007 and 2008. The decline was more severe in 2007 than in 2008, which could be the result of relatively higher maximum daily air temperature, especially from mid-July to early September in 2007 (Fig. 7). TQ decline was associated with leaf senescence, as demonstrated by decline in leaf chlorophyll content and photosynthetic rate, and decline in turf density, estimated by canopy reflectance ratio $\left(\mathrm{R}_{935} / \mathrm{R}_{661}\right)$. In addition, root surface area and root biomass declined during summer months in both years, indicating less root production and more root death occurring with increasing temperature. These observations were consistent with previous findings that summer bentgrass decline was associated with leaf senescence, decline in photosynthetic activities, and increases in root mortality (Liu and Huang, 2000; Xu and Huang, 2006). 


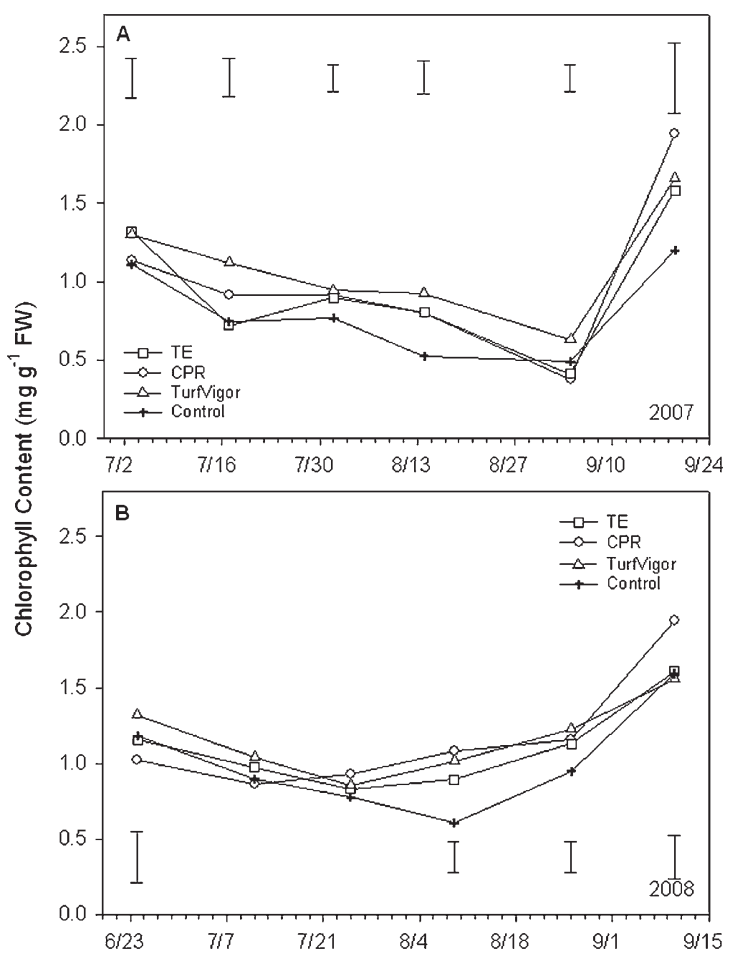

Fig. 3. Effects of TE, CPR, TurfVigor, and control treatments on chlorophyll content $\left[\mathrm{mg} \cdot \mathrm{g}^{-1}\right.$ fresh weight (FW)] of creeping bentgrass during the experimental period in 2007 (A) and 2008 (B). Vertical bars indicate least significant differences (lsds) $(P \leq 0.05)$ for treatment comparison at a given day of treatment. 1sds $(P \leq 0.05)$ for comparison among the samplings dates in 2007 are $0.29,0.41,0.30$, and $0.30 \mathrm{mg} \cdot \mathrm{g}^{-1} \mathrm{FW}$ in TE, CPR, TurfVigor, and control treatments, respectively; 1sds $(P \leq 0.05)$ for comparison among the samplings dates in 2008 are $0.47,0.36,0.33$, and $0.25 \mathrm{mg} \cdot \mathrm{g}^{-1} \mathrm{FW}$ in TE, CPR, TurfVigor, and control treatments, respectively. The lsd bars were not presented on sampling dates when treatment effects were not significant.

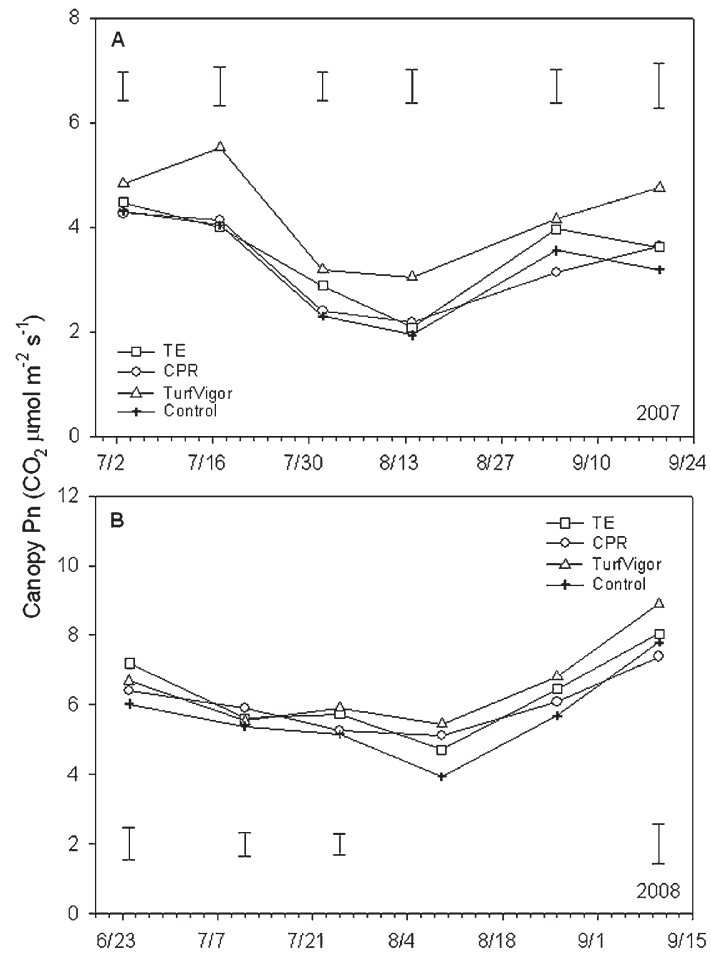

Fig. 4. Effects of TE, CPR, TurfVigor, and control treatments on canopy photosynthetic rate $\left(\mathrm{P}_{\mathrm{n}} ; \mathrm{CO}_{2}\right.$ $\mu \mathrm{mol} \cdot \mathrm{m}^{-2} \cdot \mathrm{s}^{-1}$ ) of creeping bentgrass during the experimental period in $2007(\mathbf{A})$ and $2008(\mathbf{B})$. Vertical bars indicate least significant differences (1sds) $(P \leq 0.05)$ for treatment comparison at a given day of treatment. 1sds $(P \leq 0.05)$ for comparison among the samplings dates in 2007 are $0.48,0.51,0.86$, and $0.37 \mathrm{CO}_{2} \mu \mathrm{mol} \cdot \mathrm{m}^{-2} \cdot \mathrm{s}^{-1}$ in TE, CPR, TurfVigor, and control treatments, respectively; 1sds $(P \leq 0.05)$ for comparison among the samplings dates in 2008 are $1.31,1.85,1.36$, and $1.47 \mathrm{CO}_{2} \mu \mathrm{mol} \cdot \mathrm{m}^{-2} \cdot \mathrm{s}^{-1}$ in TE, CPR, TurfVigor, and control treatments, respectively. The lsd bars were not presented on sampling dates when treatment effects were not significant.
The two biostimulants significantly improved visual quality of creeping bentgrass putting green during the summer. Higher TQ in TurfVigor or CPR-treated plots was observed on all sampling dates in both years compared with the control plots. Leaf senescence during summer was alleviated as manifested by suppression of chlorophyll loss and increased canopy density in plots treated with either product. The maintenance of higher chlorophyll and more photosynthetically active leaves enabled the maintenance of higher canopy photosynthesis in creeping bentgrass treated with TurfVigor or CPR during summer months in both years. In addition, there were some positive effects of both biostimulants on root growth of creeping bentgrass. TurfVigor-treated plots exhibited larger root surface area on 14 Aug. in 2007 and 10 Sept. in 2008 and higher root biomass on 17 July and 14 Aug. in 2007 and 26 Aug. and 10 Sept. in 2008. CPR-treated plots exhibited greater root biomass on 10 Sept. in 2008.

The growth promoting effect of seaweedextract based biostimulants is thought to be due to various organic compounds present in the seaweed extract, and more specifically, due to the presence of relatively high levels of cytokinins (Steveni et al., 1992). Cytokinins are known for their functions of suppressing leaf senescence and promoting tillering (Gan and Amasino, 1995; $\mathrm{Xu}$ et al., 2009; $\mathrm{Xu}$ and Huang 2009). Zhang and Ervin (2008) recently compared the effects of seaweedbased cytokinins with a cytokinin standard (10 $\mu \mathrm{M}$ ZR) on creeping bentgrass under heat stress $\left(35 / 25{ }^{\circ} \mathrm{C}\right.$, day/night) and found that endogenous cytokinin contents increased to comparable levels for the two treatments. Therefore, application of seaweed-based biostimulants could affect the hormone status within plants. Additionally, the adverse effects of high soil temperatures on shoot growth could be attributed to decreased nutrient uptake by roots (Fry and Huang, 2004), whereas cytokinins are related to $\mathrm{N}$ mobilization and partitioning (Goicoechea et al., 1996). Rathore et al. (2009) studied the effects of foliar applications of a seaweed extract on nutrient uptake, growth, and yield of soybean without the application of chemical fertilizers. They did observe enhanced yield as well as improved nutrient uptake $(\mathrm{N}$, phosphorus, potassium, and sulfur) with seaweed extract applications. Some studies suggested that the effects of seaweed extracts were independent of the addition of macroand microelements (Mueller and Kussow, 2005; Wrightman and Thimann, 1980). Beckett et al. (1994) investigated the effect of the seaweed concentrate Kelpak on the yield of tepary bean (Phaseolus acutifolius L.) grown under conditions of varying nutrient supply and found Kelpak significantly increased the yield of plants growing at all concentrations of nutrient supply, suggesting that seaweed extract did not act simply as a fertilizer. Alternatively, some other studies suggested the micronutrients in a seaweedbased biostimulant formulation may act mainly as enzyme catalysts (Silva et al., 


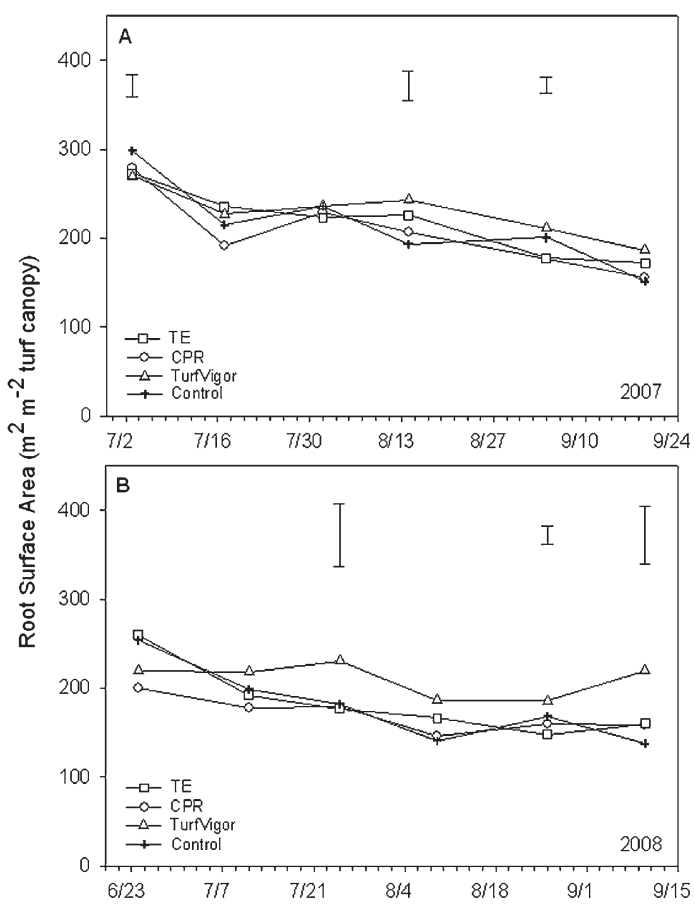

Fig. 5. Effects of TE, CPR, TurfVigorm and control treatments on total root surface area $\left(\mathrm{cm}^{2}\right)$ of creeping bentgrass during the experimental period in 2007 (A) and 2008 (B). Vertical bars indicate least significant differences (1sds) $(P \leq 0.05)$ for treatment comparison at a given day of treatment. 1sds $(P \leq$ 0.05 ) for comparison among the samplings dates in 2007 are $65.19,65.54,97.71$, and $72.89 \mathrm{~cm}^{2}$ in TE, CPR, TurfVigor, and control treatments, respectively; 1sds $(P \leq 0.05)$ for comparison among the samplings dates in 2008 are $115.07,88.94,96.23$, and $111.91 \mathrm{~cm}^{2}$ in TE, CPR, TurfVigor, and control treatments, respectively. The lsd bars were not presented on sampling dates when treatment effects were not significant.

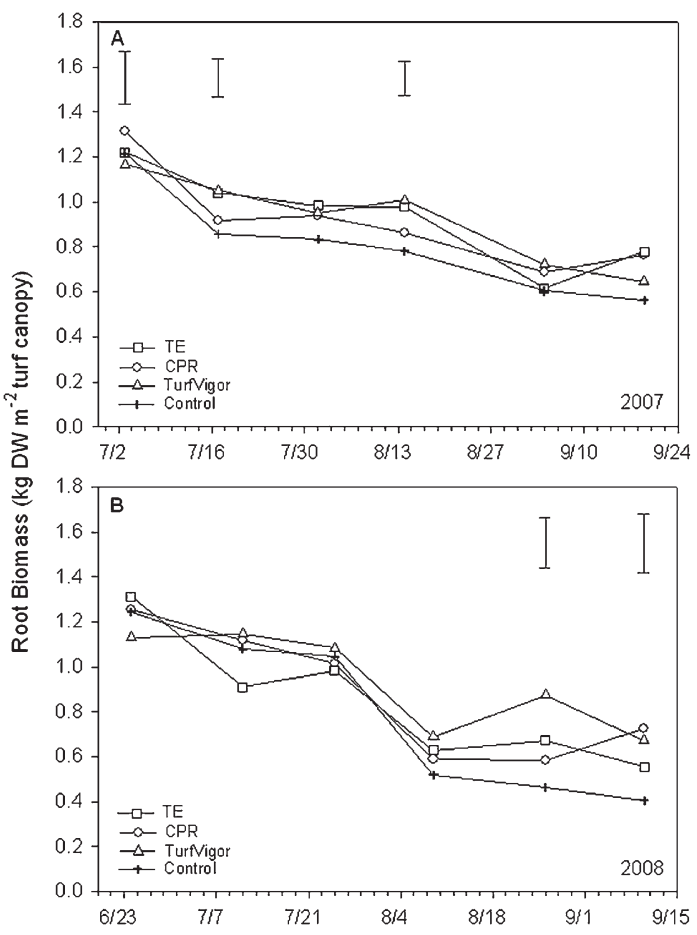

Fig. 6. Effects of TE, CPR, TurfVigor, and control treatments on root biomass ( $\mathrm{g}$ ) of creeping bentgrass during the experimental period in 2007 (A) and 2008 (B). Vertical bars indicate least significant differences (lsds) $(P \leq 0.05)$ for treatment comparison at a given day of treatment. 1sds $(P \leq 0.05)$ for comparison among the samplings dates in 2007 are $0.046,0.039,0.061$, and $0.054 \mathrm{~g}$ in TE, CPR, TurfVigor, and control treatments, respectively; lsds $(P \leq 0.05)$ for comparison among the samplings dates in 2008 are $0.069,0.054,0.044$, and $0.050 \mathrm{~g}$ in TE, CPR, TurfVigor, and control treatments, respectively. The 1sd bars were not presented on sampling dates when treatment effects were not significant.
2008). Rayorath et al. (2008) found that $A$. nodosum extract induced amylase activity in barley (Hordeum vulgare L.). Zhang et al. (2003) reported that seaweed extract applications increased superoxide dismutase activity and improved physiological activity of creeping bentgrass irrespective of fertilization regimes. The microbial strains in TurfVigor may have some additional beneficial effects but need further testing. Mueller and Kussow (2005) found the root-zone microbial community did respond to summer decline of bentgrass roots and concomitant decreases in quantities of root exudates, but the five biostimulants they tested did not effectively alter the putting green microbial community in terms of enzyme activity or substrate use.

TE treatment significantly improved TQ of creeping bentgrass from mid-August to mid-September in 2007 and from early July to mid-September in 2008 in this study. The improvement in TQ was associated with increases in green color and turf density. TE has been shown to increase total chlorophyll content per unit leaf tissue and canopy density as measured through tiller counts or visual ratings (Ervin and Koski, 1998, 2001; Fagerness and Yelverton, 2001; Stier and Rogers, 2001). We observed higher CHL on certain sampling dates (1 Aug. in 2007 and 9 Aug. in 2008) as well as denser turf canopy as reflected by higher $R_{935} / R_{661}$ ratio on 1 and 14 Aug. in 2007 and 26 Aug. and 10 Sept. in 2008 , in TE-treated plots. The effects of TE on promoting maintenance of canopy leaf area and chlorophyll content are most likely the result of a combination of decreased leaf senescence and increased tillering capability (Breuninger and Watschke, 1989; Heckman et al., 2001). Ervin and Zhang (2007) found that sequential TE treatment significantly increased leaf cytokinin (transzeatin riboside) content of creeping bentgrass, Kentucky bluegrass (Poa pratensis L.), and hybrid bermudagrass (Cynodon dactylon $\times$ C. transavaalensis) sods grown in flats under a greenhouse mist system. Han et al. (1998) reported that TE affected photoassimilate partitioning to adjacent tillers and total nonstructural carbohydrate accumulation. We observed positive effects of TE on photosynthetic activities as manifested by higher canopy net photosynthetic rates in TE-treated plots on some sampling dates, suggesting TE may increase photosynthetic capacity that could favor creeping bentgrass survival under summer stress.

TE effects on root growth were not consistent in 2007 and 2008. Greater root biomass was observed on two of the six sampling dates in 2007 but not observed in 2008. Beasley and Branham (2007) reported that TE-treated Kentucky bluegrass showed no significant difference in total root length or surface area compared with control plants under two temperature regimes (23/18 and $30 / 25^{\circ} \mathrm{C}$, day/night). Temperature and TE interactive effects on root growth were inconclusive in previous studies with other turfgrass species. Han et al. (1998) reported 


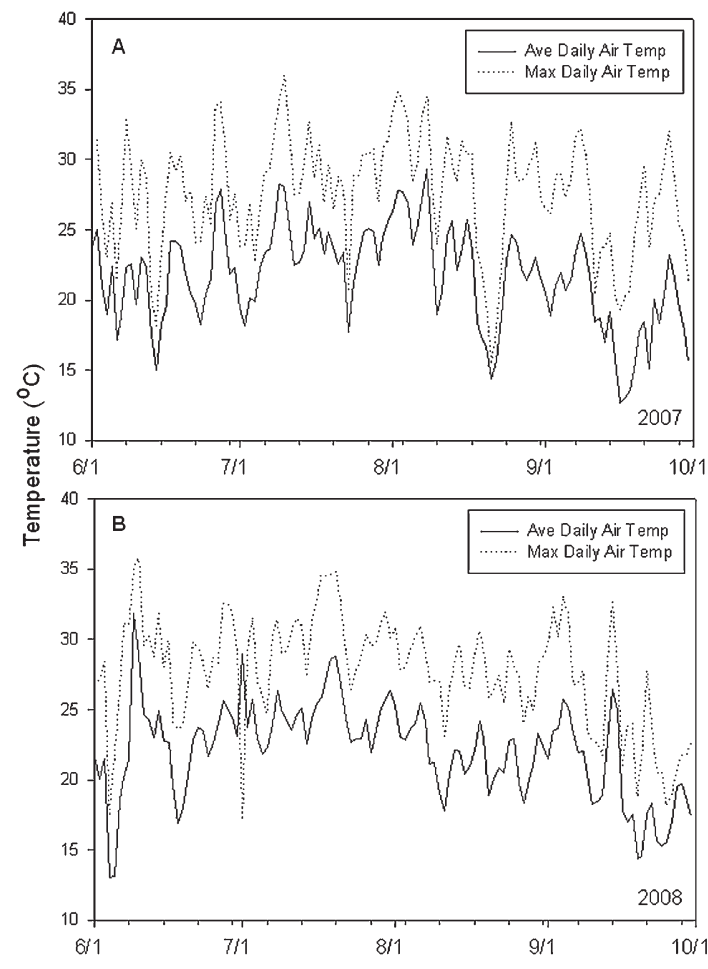

Fig. 7. Daily average and maximum air temperatures during the experimental period in 2007 (A) and 2008 (B). Data were recorded from an onsite weather station located at Horticulture Farm II, North Brunswick, NJ, $\approx 130 \mathrm{~m}$ from the experimental field plots.

TE increased root growth and root carbohydrate levels in 'Penncross' creeping bentgrass. However, in another study conducted by Fagerness and Yelverton (2001), TE did not affect root biomass of the same turf cultivars during most of the stress period and recovery. Additionally, Goss et al. (2002) found the increase in the number of tillers by TE significantly lowered the rootto-shoot ratio, because additional tillers had the same total root mass per unit area.

In summary, TE treatment significantly elevated TQ of creeping bentgrass under summer stress by alleviating leaf senescence but had limited effects on promoting root growth. The two seaweed-based biostimulants significantly improved visual quality of creeping bentgrass putting green in the summer by promoting both shoot and root growth. Application of TE and selected biostimulants following their respective label rates in a 2-week interval may be effective to improve summer performance of creeping bentgrass.

\section{Literature Cited}

Adams, R., E. Kerber, K. Pfister, and E.W. Weiler. 1992. Studies on the action of the new growth retardant CGA163935 (Primo). Kluwer, Dordrecht, The Netherlands.

Adeldipe, N.O., L.A. Hunt, and R.A. Fletcher. 1971. Effects of benzyladenine on photosynthesis, growth and senescence of bean plants. Physiol. Plant. 25:151-153.

Arnon, D.I. 1949. Copper enzymes in isolated chloroplasts. Polyphenoloxidase in Befa vulgaris. Plant Physiol. 24:1-13.

Asrar, G., M. Fuchs, E.T. Kanemasu, and J.L. Hatfield. 1984. Estimating absorbed photosyn-
Ervin, E.H. and X.Z. Zhang. 2007. Influence of sequential trinexapac-ethyl applications on cytokinin content in creeping bentgrass, Kentucky bluegrass, and hybrid bermudagrass. Crop Sci. 47:2145-2151.

Ervin, E.H., X.Z. Zhang, S.D. Askew, and J.M. Goatley. 2004. Trinexapac-ethyl, propiconazole, iron, and biostimulant effects on shaded creeping bentgrass. HortTechnology 14:500506.

Fagerness, M.J. and F.H. Yelverton. 2001. Plant growth regulator and mowing height effects on seasonal root growth of penncross creeping bentgrass. Crop Sci. 41:1901-1905.

Fagerness, M.J., F.H. Yelverton, D.P. Livingston, and T.W. Rufty. 2002. Temperature and trinexapacethyl effects on bermudagrass growth, dormancy, and freezing tolerance. Crop Sci. 42:853-858.

Fry, J. and B. Huang. 2004. Applied turfgrass science and physiology. John Wiley \& Sons, Inc, Hoboken, NJ.

Gan, S.S. and R.M. Amasino. 1995. Inhibition of leaf senescence by autoregulated production of cytokinin. Science 270:1986-1988.

Goicoechea, N., M.C. Antolin, M. Strnad, and M. SanchezDiaz. 1996. Root cytokinins, acid phosphatase and nodule activity in droughtstressed mycorrhizal or nitrogen-fixing alfalfa plants. J. Expt. Bot. 47:683-686.

Goss, R.M., J.H. Baird, S.L. Kelm, and R.N Calhoun. 2002. Trinexapac-ethyl and nitrogen effects on creeping bentgrass grown under reduced light conditions. Crop Sci. 42:472479.

Green Section Staff. 1993. USGA recommendations for a method of putting green construction. USGA Green Sect. Rec. 31:1-3.

thetic radiation and leaf area index from spectral reflectance in wheat. Agron. J. 76:300-306.

Beard, J.B. 1973. Turfgrass: Science and culture. Prentice-Hall, Englewood Cliffs, NJ.

Beard, J.B. and W.H. Daniel. 1966. The relationship of creeping bentgrass (Agrostis palustris Huds.) root growth to environmental factors in the field conditions. Agron. J. 58:337-339.

Beasley, J.S. and B.E. Branham. 2007. Trinexapacethyl and paclobutrazol affect Kentucky bluegrass single-leaf carbon exchange rates and plant growth. Crop Sci. 47:132-138.

Beckett, R.P., A.D.M. Mathegka, and J. Vanstaden. 1994. Effect of seaweed concentrate on yield of nutrient-stressed tepary bean (PhaseolusAcutifolius Gray). J. Appl. Phycol. 6:429-430.

Bokil, K.K., V.C. Mehta, and D.S. Datar. 1974. Seaweeds as manure II: Pot culture manorial experiments on wheat. Phykos 13:1-5.

Borger, J.A. 2008. Managing Poa annua seedheads on putting greens. USGA Green Section Record 46:7-8.

Breuninger, J.M. and T.L. Watschke. 1989. Growth regulation of turfgrass. Rev. Weed Sci. 4:153167.

Carrow, R.N. 1996. Summer decline of bentgrass greens. Golf Course Mgt. 64:51-56.

Crouch, I.J. and J. van Standen. 1992. Effect of seaweed concentrate on the establishment and yield of greenhouse tomato plants. J. Appl. Phycol. 4:291-296.

DaCosta, M. and B.R. Huang. 2006. Minimum water requirements for creeping, colonial, and velvet bentgrasses under fairway conditions. Crop Sci. 46:81-89.

Ervin, E.H. and A.J. Koski. 1998. Growth responses of Lolium perenne L. to trinexapacethyl. HortScience 33:1200-1202.

Ervin, E.H. and A.J. Koski. 2001. Trinexapac-ethyl increases Kentucky bluegrass leaf cell density and chlorophyll concentration. HortScience 36:787-789.
Han, S.W., T.W. Fermanian, J.A. Juvik, and L.A. Spomer. 1998. Growth retardant effects on visual quality and nonstructural carbohydrates of creeping bentgrass. HortScience 33:11971199 .

Hatfield, J.L., E.T. Kanemasu, G. Asrar, R.D. Jackson, P.J. Pinter, R.J. Reginato, and S.B. Idso. 1983. Leaf area estimators from spectral measurements over various planting dates of wheat. Intl. J. Remote Sens. 6:167-175.

Heckman, N.L., G.L. Horst, R.E. Gaussoin, and L.J. Young. 2001. Heat tolerance of Kentucky bluegrass as affected by trinexapac-ethyl. HortScience 36:365-367.

Henson, I.E. and P.F. Wareing. 1976. Cytokinins in Xanthium strumarium L.: Distribution in the plant and production in the root system. J. Expt. Bot. 27:1268-1278.

Huang, B. 2001. Summer bentgrass decline: Causes and cures. Golf Course Mgt. 69:61-64.

Huang, B.R. and Q.Z. Xu. 2000. Root growth and nutrient element status of creeping bentgrass cultivars differing in heat tolerance as influenced by supraoptimal shoot and root temperatures. J. Plant Nutr. 23:979-990.

Jiang, Y.W. and R.N. Carrow. 2005. Assessment of narrow-band canopy spectral reflectance and turfgrass performance under drought stress. HortScience 40:242-245.

Jiang, Y.W. and R.N. Carrow. 2007. Broadband spectral reflectance models of turfgrass species and cultivars to drought stress. Crop Sci. 47: $1611-1618$

Karnok, K.J. 2000. Promises, promises: Can biostimulants deliver? Golf Course Mgt. 68:67-71.

Kaufmann, J.E. 1986. The role of PGR science in Growth Regulat. Soc. Amer 13:2-14.

King, R.W., G.F.W. Gocal, and O.M. Heide. 1997. Regulation of leaf growth and flowering of cool chemical vegetation control. Proc. Plant 
season turfgrasses. Proc. Intl. Turfgrass Res. Conf. 8:565-573.

Lickfeldt, D.W., D.S. Gardner, B.E. Branham, and T.B. Voigt. 2001. Implications of repeated trinexapac-ethyl applications on Kentucky bluegrass. Agron. J. 93:1164-1168.

Liu, X.Z. and B.R. Huang. 2000. Heat stress injury in relation to membrane lipid peroxidation in creeping bentgrass. Crop Sci. 40:503-510.

Liu, X.Z. and B.R. Huang. 2005. Root physiological factors involved in cool-season grass response to high soil temperature. Environ. Exp. Bot. 53:233-245.

McCann, S.E. and B.R. Huang. 2007. Effects of trinexapac-ethyl foliar application on creeping bentgrass responses to combined drought and heat stress. Crop Sci. 47:2121-2128.

McCullough, P.E., H. Liu, and L.B. McCarty. 2005. Trinexapac-ethyl application regimes influence creeping bentgrass putting green performance. HortScience 40:2167-2169.

Mueller, S.R. and W.R. Kussow. 2005. Biostimulant influences on turfgrass microbial communities and creeping bentgrass putting green quality. HortScience 40:1904-1910.

Rathore, S.S., D.R. Chaudhary, G.N. Boricha, A. Ghosh, B.P. Bhatt, S.T. Zodape, and J.S. Patolia. 2009. Effect of seaweed extract on the growth, yield and nutrient uptake of soybean (Glycine max) under rainfed conditions. S. Afr. J. Bot. 75:351-355.

Rayorath, P., W. Khan, R. Palanisamy, S.L. MacKinnon, R. Stefanova, S.D. Hankins, A.T. Critchley, and B. Prithiviraj. 2008. Extracts of the brown seaweed Ascophyllum nodosum induce gibberellic acid [GA(3)]independent amylase activity in barley. J. Plant Growth Regul. 27:370-379.

Sanderson, K.J., P.E. Jameson, and J.A. Zabkiewicz. 1987. Auxin in a seaweed extract: Identification and quantitation of indole-3-acetic acid by gas chromatography-mass spectrometry. J. Plant Physiol. 129:363-367.

Silva, T.T.D., E.V.D. Von Pinho, D.L. Cardoso, C.A. Ferreira, P.D. Alvim, and A.A.F. da Costa. 2008. Physiological quality of corn seeds in the presence of biostimulants. Ciencia E. Agrotecnologia. 32:840-846.

Steveni, C.M., J. Norringtondavies, and S.D. Hankins. 1992. Effect of seaweed concentrate on hydroponically grown spring barley. J. Appl. Phycol. 4:173-180.

Stier, J.C. and J.N. Rogers. 2001. Trinexapac-ethyl and iron effects on supina and kentucky bluegrasses under low irradiance. Crop Sci. 41:457-465.

Tay, S.A.B., J.K. Macleod, L.M.S. Palni, and D.S. Letham. 1985. Detection of cytokinins in a seaweed extract. Phytochemistry 24:2611-2614.

Trenholm, L.E., R.N. Carrow, and R.R. Duncan. 1999. Relationship of multispectral radiometry data to qualitative data in turfgrass research. Crop Sci. 39:763-769.

Udomprasert, N., P.H. Li, D.V. Davis, and A.H. Markhart. 1995. Root cytokinin level in relation to heat tolerance of Phaseolus acutifolius and Phaseolus vulgaris. Crop Sci. 35:486-490.

Wang, Z., J. Sun, and Y. Zhu. 2006. Heat resistance enhanced by trinexapac-ethyl and benzyladenine combination in creeping bentgrass. HortScience 41:1711-1714.
Wells, C., A. LaBranche, L.B. McCary, and H. Skipper. 2003. Can biostimulants improve bentgrass root growth? Turfgrass Trends May 2003.

Wrightman, F. and K.V. Thimann. 1980. Hormonal factors controlling the initiation and development of lateral roots. I: Source of primordiainducing substances in the primary root of pea seedlings. Physiol. Plant. 49:13-20.

Xu, Q.Z. and B.R. Huang. 2000. Growth and physiological responses of creeping bentgrass to changes in air and soil temperatures. Crop Sci. 40:1363-1368.

Xu, Q.Z. and B.R. Huang. 2006. Seasonal changes in root metabolic activity and nitrogen uptake for two cultivars of creeping bentgrass. HortScience 41:822-826.

$\mathrm{Xu}, \mathrm{Y}$. and B. Huang. 2009. Effects of foliar applied ethylene inhibitor and synthetic cytokinin on creeping bentgrass to enhance heat tolerance. Crop Sci. 49:1876-1884.

Xu, Y., J. Tian, T. Gianfagna, and B.R. Huang. 2009. Effects of SAG12-ipt expression on cytokinin production, growth and senescence of creeping bentgrass (Agrostis stolonifera L.) under heat stress. Plant Growth Regulat. 57:281-291.

Zhang, X.Z. and E.H. Ervin. 2008. Impact of seaweed extract-based cytokinins and zeatin riboside on creeping bentgrass heat tolerance. Crop Sci. 48:364-370.

Zhang, X.Z., E.H. Ervin, and R.E. Schmidt. 2003. Physiological effects of liquid applications of a seaweed extract and a humic acid on creeping bentgrass. J. Amer. Soc. HortScience 128:492496. 